\title{
EFFECT OF INFORMAL SECTOR TAX REVENUE ON CAPITAL DEVELOPMENT IN LAGOS METROPOLIS
}

\section{Jayeola OLABISI ${ }^{1,}$ Adegboyega AFOLABI ${ }^{2}$, Adebayo OLAGUNJU ${ }^{3}$, Folasade Ajewole MADARIOLA ${ }^{4}$}

\author{
${ }^{1}$ Federal University of Agriculture, Abeokuta, Nigeria \\ ${ }^{2,4}$ Crescent University, Abeokuta, Nigeria \\ ${ }^{3}$ Osun State University, Osogbo, Nigeria
}

Corresponding author e-mail: olabisij@funaab.edu.ng

\begin{abstract}
The study investigates the effect of informal sector tax proceeds on capital development in Lagos Metropolis. The study adopted Ex-post facto design to obtain secondary data, covering 20 years (2000-2019) from the Lagos State Internal Revenue Service and the Ministry of Budget and Planning. All the series were tested for normalities to determine the appropriateness of Ordinary Least Square (OLS) regression. The results of the study revealed that tax collected from the association, petty traders, and market men and women had a significant effect on capital development in Lagos Metropolis. It is evident from the monumental capital projects being executed by the government in the Metropolis. The study recommends that the government should not only create an enabling environment for the informal sector to thrive but also give all necessary support for its survival because the sector has contributed to the capital development of the Metropolis through tax revenue.
\end{abstract}

Keywords: Association; Market women and men; Petty traders and Capital development.

JEL Classification: $\mathrm{H} 2 ; \mathrm{H} 23 ; 25 ; 26$

\section{INTRODUCTION}

Tax revenue is a major source of income for the government to perform civic obligations to the citizens. Tax income helps achieve economic growth and stabilise the economy, such as contending economic depression, persistent rise or fall in prices of goods and services and attainment of rightful sharing of state earnings and fortune that tackle subjects of poverty and promotion of socio-economic development in the country (Ofoegbu, Akwu \& Oliver, 2016). Tax revenue mobilization serves as a major source of funding the growing activities in Nigeria. Adeleke (2015) opines that tax revenue is a prevailing instrument of economic reforms and a key actor within the economy.

The growing cost of government administration together with declining income has taught governments in Nigeria to improve revenue base (Adegboyega, Olabisi, Kajola, \& Asaolu, 2019). The informal sector has presented the hope of 
engendering additional income to compensate for the shortfall in tax revenue. The informal economy is a concept originally introduced by the International Labour Organisation and is described as "a way of doing things" and has seven drivers which include ease of entry; reliance on indigenous resources; family ownership; small-scale operation; labour intensive and adaptive technologies; unregulated and competitive markets.

Oduwole and Sanni (2014) assert that an unpublished survey in 2008 put the total of informal sector in Nigeria at about $90 \%$ of new jobs in the country, about $80 \%$ of all non-agricultural employment and about $60 \%$ of urban jobs created. This has earned the sector the pivotal of being massive, diverse and the mainstay of the formal sector. Despite this fact, Oduwole and Sanni (2014) argue that its contribution to the national revenue in the form of tax is minimal. The reasons adduced include unavailability of acceptable data on operators; the absence of conventional accounting practices, poor internal record keeping, and cash based nature of most transactions and the absence of essential records with relevant revenue authorities. Hence, it becomes difficult to assess their levels of tax liability and track compliance with tax authorities. It causes huge revenue leakage and greatly increases the tax gap within the Nigerian tax system.

Widespread informal activities of the informal sector are usually regarded to be a persistent phenomenon in developing countries. It has been suggested that some of the largest and fastest-growing business sectors in Nigeria, such as the retail and construction, are dominated by informal activities and entrepreneurs Kundt, 2017). Although the informal sector exists in both developing and developed countries, the context of their environment, cultures, and dynamics shape their evolution. It is difficult to track the growth and contribution of most of the players in this sector because of their transitory life cycle, modus operandi and lack of institutional records by the State and Federal Government in Nigeria (Adeleke, 2015).

Given the above, the operations and features of the informal sector coupled with the quantum of tax revenue from the sector as grouped by the government, various studies have not been able to establish the proper links between the tax revenue from the sector with the capital development of the country. Hence, the study examines the effect of informal sector tax revenue on capital development in Lagos Metropolis. Specific objectives are as follows:

- to examine the effect of tax revenue from associations on capital development in Lagos Metropolis;

- to investigate the effect of tax revenue from market men and women on capital development in Lagos Metropolis;

- to evaluate the effect of tax revenue from petty traders on capital development in Lagos Metropolis.

The preceding parts of the paper deal with conceptual, theoretical and empirical review. The third section discusses the methodology adopted in the study. The forth part presents the results of the study, while the fifth section discusses the findings. The last section of the paper concludes and makes recommendations contingent upon the outcome of the study. 


\section{LITERATURE REVIEW}

\subsection{Conceptual Reviews}

\section{Tax Revenue of Informal Sector}

Informal sector and its tax revenue has been variously defined by several authors that have contributed to this discussion. The informal economy is described as the sum total of economic activity that happens outside state regulation, which is neither taxed nor represented in a country's Gross Domestic Product (Enahoro \& Olabisi, 2014). It has also been described as economic activities that lack conventional accounting procedures characterised by high rates of non-reporting or underreporting and left out from social measurement device such as the Gross Domestic Product (Oduwole \& Sanni, 2014).

The informal sector is an enterprise that employs one to nine people (Adesoji $\&$ Chike, 2016). It covers a wide sector and it includes manufacturing, trading, and services. The sector includes market traders, artisans (mechanics, technicians), cottage industrialists, petty hawkers, transport workers, small shops, and micro businesses. Built on experience, a probable tax system is capable of reducing the chances of evading taxes because it eliminates the onus of self-assessment from the informal sector, such that the duty of evaluating taxable income rests on the tax authority (Adesoji \& Chike, 2016).

Oduwole and Sanni (2014) conclude that a key attribute of a faithful and just tax scheme is equity where tax payers pay based on their ability. However, the existing tax system in Nigeria, where workers in the formal sector pay tax accordingly because there are records and whereas higher income earners in the informal sector continue to evade and avoid tax or even worse, where unlucky petty traders and market men and women are hassled by multiple taxes but richer and cleverer informal business persons pay nothing, is far from being fair and such tax supervision is not efficient.

\section{Association (ASS)}

Trading association is a voluntary, non-profit making organisation for mutual benefit or advantage of independent enterprise manufacturing or distributing comparable goods and services. A Trade Association is an industry trade group, business association or industrial body established and funded by businesses that operate in a specific line of business (Adum, 2018). Affiliation criteria seem neither unrealistic nor exclusionary, except that some traders or service providers may feel unable to meet the fees (Odoemelam, 2018).

\section{Petty Trading (PT)}

Petty trading refers to an economic activity that comprises retailing (and buying) goods and services on a small scale, ranging from agricultural produce to imported consumer goods. It constitutes a group of individual sellers with small capital and buyers operating in a group of small spaces (David, 2016). Petty trading activity has become an important sphere of the informal sector that plays a 
momentous role in urban economic life. Certain commodities are not capable of being sold to ultimate consumers by the formal sector such as fruits, vegetables, groundnuts, retail biscuits, spoons, pan, cigarettes, cosmetics, jewellery, ladies' bags and wallets, second-hand clothes (Musa \& Acheampong, 2014).

\section{Market Men and Women (MMW)}

Market men and women have shops in the same and different markets in Lagos State. There are periodic markets outside and within the cities, while the periodic market places serve the traditional needs; the trading centres serve as bridges between export enclaves and the produce markets in the rural areas (Gilson, 2015). There are normally periodic market places in rural areas and daily marketplaces are dominant in urban areas by market men and women.

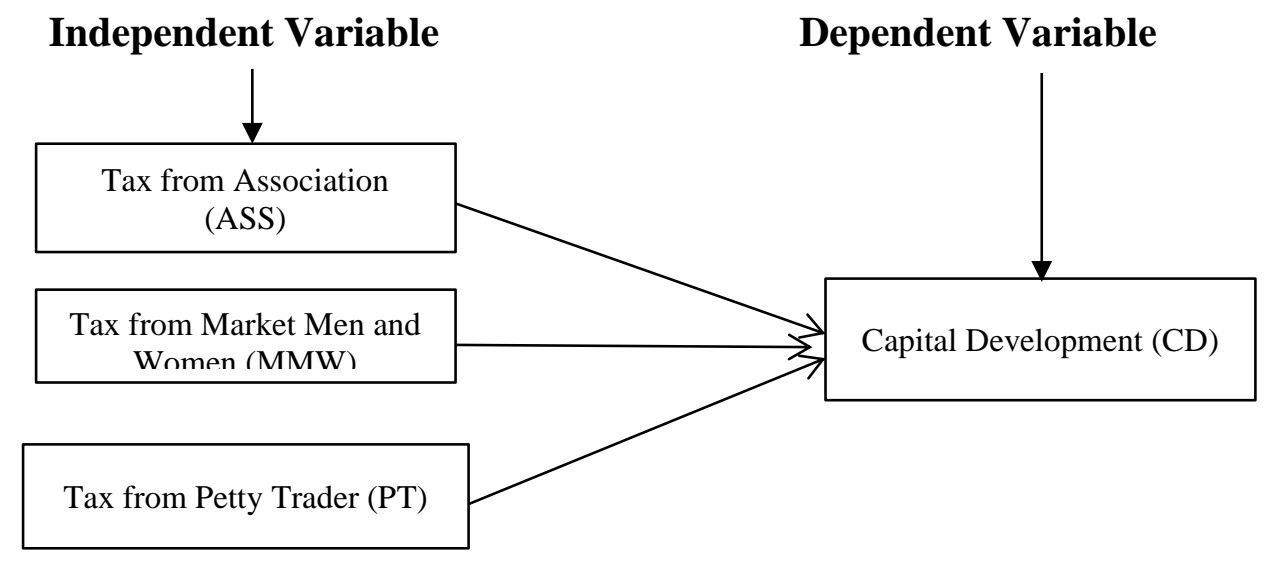

Fig. 1. Operationalization of variables (authors' conceptual model, 2019).

\subsection{Theoretical Review}

The study is anchored on the expediency theory because of its numerous advantages and capability in boosting the tax yield of the government. It is a robust and dynamic model of administrative tool developed to respond to the administrative, technical and technological attitudes of the taxpayers to have enough funds to take care of state activities for capital development.

Bhartia (2009) pointed out that a taxation theory evolved on the supposition that there was no link between tax generated by the government and the services rendered by the government. The absence of a direct link between tax collected from taxpayers and services rendered by the government to the taxpayers presents the tax payment as a compulsory obligation and is not motivating. The expediency theory proposes that every government tax policy should be subjected to the practicality test. This should be the only factor to assess the selection of tax schemes by the government of every state (Bhartia, 2009; Appah \& Eze, 2014; Udoh, 2015).

Taxation offers a commanding set of rules that should be well adapted to salvage the declining economy and correct social injustice in the society such as income disparities, regional inequalities, and joblessness. Wahdan and Leithy (2017) endorsed social and political impartial to be a major feature to select a tax 
system. They purported that an appropriate solution shall be devised when the economic challenge is considered alongside with associated social and political framework. Therefore, a tax system should be designed to correct the social and economic imbalance in society and rather than serve individual members of society.

Finally, it is unreasonable to impose taxes on people, if a tax cannot be properly and efficiently collected. However, given a set of diverse feasible taxes and realistic rates, a selection should be made regarding their conceivable influence on the functionality of the economy. The expediency approach does not aid the government to resolve the unalike realistic taxes and those that bear the burden of a new tax or modification to the prevailing tax system but argues that the existing tax is not workable.

\subsection{Empirical Review}

Guillermo and Deyve (2019) examined the size of informal economy in Peru, Latin America and OCDE countries as well as estimated the impact of the informal economy on tax revenue and economic growth. The study adopted the Multiple Indicator and Multiple Cause (MIMIC) model. The results showed that the estimated average size of informal economy on tax revenue as a percentage of GDP was $37.4 \%$ in Peru, in Latin America it was $34 \%$ and in OCDE countries $-19.89 \%$ representing less than half of the average in Latin America.

Ameyaw, Oppong, Abruquah and Ashalley (2016) assessed the Informal Sector Tax Compliance issues and the casualties between Taxation and Economic Growth with empirical evidence from Ghana. The research was divided into two parts. Questionnaires were administered to 600 respondents comprising informal sector taxpayers in all the ten regions of Ghana, as well as the regression analysis was employed. The second part of the study examined the casualty between taxes and GDP in Ghana's economy in the period of 1980-2015 using the Augmented Dickey Fuller Unit Root test. The results revealed that attitudes, subjective norms, and perceived behavioural control were the main determinants of the informal sector compliance factor. The study recommended that efforts should be geared towards improving tax systems to augment the GDP of the country.

Obara and Nangih (2017) examined the effect of taxing the informal sector in Nigeria with a focus on the River state. A descriptive research design and a judgemental and convenience sampling technique were adopted. The data collected were analysed using Kruskal Wallis and Chi-square tests to examine the formulated hypotheses. The findings revealed that taxing the informal sector boosted revenue generation and positively affected the economic development of developing states in Nigeria.

Ramot and Ichihashi (2015) used panel data from 65 countries during the period of 1975-2011 to assess the effects of the tax structure on economic growth and income inequality. Ordinary Least Square method of analysis was adopted. The study showed that Company Income Tax (CIT) rates had a negative impact both on economic growth and income inequality. It was also found out that the Personal Income Tax (PIT) rate did not significantly affect economic growth and income inequality. The study recommended developing and introducing a modest design into the tax system in Nigeria. 


\section{METHODOLOGY}

To achieve the objective of the study, Ex-post facto design was used by obtaining secondary data (covering a period of 2000-2019) from the Lagos State Internal Revenue Service and the Ministry of Budget and Planning.

The data were accepted to be appropriate for the study due to the following reasons:

i. They were already validated by professionals and other regulatory bodies before being published by the Ministry of Budget and Planning;

ii. Secondary data were consistently used in prior studies and produced good results.

The study adopted a quantitative data analysis technique and was undertaken in four stages, which included the performance of descriptive analysis using the mean, minimum, maximum, and skewness. It was done with a view to describing the data set to fix the normality of the series. Thus, a $p$-value of Jacque Berra's statistics was higher than the accepted level of significance of $5 \%$ representing that the series was normally distributed. Since normalities of the series were one of the central suppositions of performing Ordinary Least Square (OLS) regression, all the series were tested from 2000 to 2019. Furthermore, a trend analysis was undertaken to define the trend of each of the independent variables on the dependent variable. Third, the study examined the interaction among each measure of tax revenue. Last, the study employed the Ordinary Least Square analysis to determine the extent to which each of the independent variables had contributed to the dependent variable and coefficient of determination was employed to establish the degree to which each of the independent variables explained the effect on the capital development in Lagos Metropolis.

\subsection{Research Hypotheses}

The following hypotheses were formulated and tested:

Ho1: Tax revenue from associations has no significant impact on capital development in Lagos Metropolis.

Ho2: Tax revenue from market men and women has no significant impact on capital development in Lagos Metropolis.

Ho3: Tax revenue from petty traders has no significant impact on capital development in Lagos Metropolis.

\subsection{Model Specification}

To achieve the main objective, two variables were identified in the study: independent and dependent variables. The independent variables are informal sector tax revenue with the following dimensions as surrogates: petty traders, associations, market men and women; the dependent variable, on the other hand, is capital development measured by education, housing and health sector development for the period under study. The following models were adopted:

Capital Development $=f($ Informal Sector Tax Revenue $)$. 
Therefore, Equation (1) becomes:

$$
C D_{t}=f\left(A S S_{t}, M M W_{t}, P T_{t}\right) .
$$

Operationalizing Equation (2) becomes:

$$
C D_{t}=\alpha_{0}+\alpha_{1} A S S_{t}+\alpha_{2} M M W_{t}+\alpha_{3} P T_{t}+e_{t},
$$

where

$C D$ - capital development ( ' billion);

$A S S$ - tax revenue from associations ( ${ }^{\prime}$ billion);

$M M W$ - tax revenue from market men and women ( billion);

$P T$ - tax revenue from petty traders ( $\aleph^{\prime}$ billion);

$e$ - error term;

$\alpha_{0}-$ constant;

$\alpha_{1}-\alpha_{3}-$ coefficients estimated;

$t$ - time (2000-2019).

\section{A-Priori Expectation}

The expected signs of the coefficient of the explanatory variable are as follows:

○ $\alpha_{0}<0, \alpha_{1}>0, \alpha_{2}>0, \alpha_{3}>0$

○ $\alpha_{0}$ is expected to be negative because other factors determine capital development aside from the ones stated in the model;

- $\alpha_{1}$ is expected to be positive because prompt tax revenue from associations is expected to boost the state spending on capital development;

○ $\quad \alpha_{2}$ is expected to be positive because prompt tax revenue from market men and women is expected to boost the state spending on capital development;

- $\alpha_{3}$ is expected to be positive because prompt tax revenue from petty traders is expected to boost the state spending on capital development.

\section{Decision Rule}

If $t$ calculated value is less than $t$ critical table value, Accept $H_{0}$ and Reject $H_{1}$. If $t$ calculated value is more than $t$ critical table value, Accept $H_{1}$ and Reject $H_{0}$. $H_{0}$ means the individual independent variable does not assert statistical significance on the dependent variable, while $H_{1}$ means the individual independent variable asserts statistical significance on the dependent variable. 
Table 1. Measurement of Variables (authors' synthesis of the report from Lagos State Ministry of Finance, Budget and Planning)

\begin{tabular}{|l|l|l|}
\hline Variables & \multicolumn{1}{|c|}{ Variable type } & \multicolumn{1}{c|}{ Measurements } \\
\hline$C D$ & Dependent variable & $\begin{array}{l}\text { Total annual expenditure on housing, hospital and health } \\
\text { services divided by total annual tax revenue from the } \\
\text { informal sector }\end{array}$ \\
\hline$A S S$ & Independent & $\begin{array}{l}\text { Total annual tax collected from trading association } \\
\text { divided by total annual tax revenue from the informal } \\
\text { sector }\end{array}$ \\
\hline$M M W$ & Independent & $\begin{array}{l}\text { Total annual tax collected from } M M W \text { divided by total } \\
\text { annual revenue from the informal sector }\end{array}$ \\
\hline$P T$ & Independent & $\begin{array}{l}\text { Total annual tax collected from } P T \text { divided by total } \\
\text { annual revenue from the informal sector }\end{array}$ \\
\hline
\end{tabular}

\section{DATA PRESENTATION}

\subsection{Descriptive Statistics}

The table below describes the behaviour of the variables adopted in the study, which included independent variable measured with Association (ASS), Market Men and Women $(M M W)$, Petty Traders $(P T)$ and Capital Development $(C D)$ as the dependent variable.

Table 2. Descriptive Statistics (authors' computation, 2019)

\begin{tabular}{|l|c|c|c|c|}
\hline & $\boldsymbol{C D}$ & $\boldsymbol{A S S}$ & $\boldsymbol{M M W}$ & $\boldsymbol{P T}$ \\
\hline Mean & 0.115500 & 3.532500 & 1.905000 & 4.843000 \\
\hline Median & 0.100000 & 3.100000 & 1.450000 & 3.690000 \\
\hline Maximum & 0.380000 & 6.330000 & 6.400000 & 2.130000 \\
\hline Minimum & 0.020000 & 2.060000 & 0.100000 & 0.290000 \\
\hline Std. Dev. & 0.095833 & 1.222426 & 1.563220 & 4.340922 \\
\hline Skewness & 0.981935 & 1.009641 & 2.274929 & 2.857333 \\
\hline Kurtosis & 4.062598 & 2.991482 & 7.066349 & 11.58061 \\
\hline Jarque-Bera & 4.154917 & 3.397975 & 3.103034 & 8.857018 \\
\hline Probability & 0.125248 & 0.182869 & 0.000000 & 0.000000 \\
\hline Observations & 20 & 20 & 20 & 20 \\
\hline
\end{tabular}

Note: ASS = Association Tax; MMW = Market Men and Women Tax; $P T=$ Petty Traders Tax and $C D=$ Capital Development

The results (Table 2) of descriptive statistics revealed that the minimum tax collected from associations (ASS) was 2.060, while the maximum tax was 6.330 . The mean of ASS was 3.533 with a standard deviation of 1.222 . The minimum tax collected from market men and women $(M M W)$ was 0.100 , while the maximum tax was 6.400 . The mean of $M M W$ was 1.905 with a standard deviation of 1.563 . The 
minimum tax collected from petty traders $(P T)$ was 0.290 , while the maximum tax was 2.130. The mean of $P T$ was 4.834 with a standard deviation of 4.341 . The minimum amount spent on capital development $(C D)$ was 0.020 , while the maximum amount was 0.380 . The mean of $C D$ was 0.116 with a standard deviation of 0.096. It implied that the highest revenue from the informal sector was generated from the association and the lowest revenue - from petty traders.

$A S S, M M W, P T$ and $C D$ were all positively skewed or rightward skewed. The probability values of kurtosis of $C D, M M W$ and $P T$ were leptokurtic as they were all greater than 3, while the values of Kurtosis of ASS indicated that the variable was platykurtic or flat $(<3)$.

In conclusion, Jarque-Bera statistics was used to further clarify the normality of the data for the variables; critical appraisal of the Jarque-Bera statistics revealed that $C D$ and $A S S$ were normally distributed with the probability values greater than significance level of $5 \%$, while those of $M M W$ and $P T$ were less than $5 \%$ indicating non-normality of the variables.

\subsection{Correlation Analysis}

Table 3 presents the correlation matrix showing correlation between the dependent and independent variables. The results revealed that the explanatory variables of the association, market men and women and petty traders were positively correlated with capital development. The results demonstrated that the correlation between explanatory variables and response variables was weak in both cases.

Table 3. Correlation (authors' computation, 2019)

\begin{tabular}{|c|c|c|c|c|}
\hline Probability & $\boldsymbol{C D}$ & $\boldsymbol{A S S}$ & $\boldsymbol{M M W}$ & $\boldsymbol{P T}$ \\
\hline$C D$ & 1.000000 & & & \\
\hline & - & & & \\
\hline$A S S$ & 0.124886 & 1.000000 & & \\
\hline & 0.5999 & - & & \\
\hline$M M W$ & 0.182497 & 0.170867 & 1.000000 & \\
\hline & 0.4412 & 0.4714 & - & \\
\hline$P T$ & 0.040102 & 0.372157 & 0.090563 & 1.000000 \\
\hline & 0.8667 & 0.1061 & 0.7042 & - \\
\hline
\end{tabular}

Table 3 further revealed that the highest correlation among independent variables was between association and petty traders, i.e., 0.372. Judge, Griffiths, Hill, Luthepohl and Lee (1985) argue that the simple correlation between independent variables should not be considered harmful until it exceeds 0.8 or 0.9 . 


\subsection{Granger Causality Test}

The causality test among the series revealed that there was no causality between $A S S$ and $M M W$, on the one hand, and $P T$ and $A S S$ on the other hand (see Table 4). Furthermore, there was no causality between $P T$ and $M M W$.

Table 4. Pairwise Granger Causality Test (authors' computation, 2019)

\begin{tabular}{|c|c|c|c|c|}
\hline $\begin{array}{c}\text { Direction of } \\
\text { causality }\end{array}$ & $\begin{array}{c}\text { Null } \\
\text { hypothesis }\end{array}$ & $\begin{array}{c}\text { F-statistics } \\
\text { computed }\end{array}$ & $\begin{array}{c}\mathbf{5} \% \text { critical } \\
\text { value }\end{array}$ & Decision \\
\hline$A S S$ to $M M W$ & No causality & 1.20373 & 0.3314 & Accept null hypothesis \\
\hline$P T$ to $A S S$ & No causality & 0.43616 & 0.6556 & Accept null hypothesis \\
\hline$P T$ to $M M W$ & No causality & 0.06377 & 0.2385 & Accept null hypothesis \\
\hline
\end{tabular}

\subsection{Unit Root Test}

The unit root test is a time series process where the current values comprise the last period's value that presents a dependent disturbance. To avoid spurious results in the study, stationarity test of variables was performed using the Augmented Dickey Fuller test for unit root.

Table 5. Unit Root Test Results (authors' computation, 2019)

\begin{tabular}{|c|c|c|}
\hline \multirow{2}{*}{ Variables } & \multicolumn{2}{|c|}{ Augmented Dickey Fuller } \\
\cline { 2 - 3 } & First Difference & Order of integration \\
\hline Capital Development & $-3.540371(0.0182)$ & $1(0)$ \\
\hline Association & $-4.928821(0.0011)$ & $1(0)$ \\
\hline Market Men and Women & $-5117425(0.0007)$ & $1(0)$ \\
\hline Petty Traders & $-4.484935(0.0026)$ & $1(0)$ \\
\hline
\end{tabular}

The test showed that all the variables were integrated at level. Hence, it is safely concluded that the series are stationary at this level. It implies that the unit root test showed a combination of stationarity variables at level 1(0) across the independent and dependent variables. Econometric theory suggests a regression model for the variables.

\subsection{Regression Estimate Results}

Table 6 reveals the results that capture relationship amongst the series, using the Ordinary Least Squares (OLS) estimation technique.

The results showed that taxes from $A S S, M M W$ and $P T$ which in sync with $a$ priori expectations were statistically significant in contributing to the capital development in Lagos metropolis at $5 \%$ level. These results invalidated the null hypotheses for association, market men and women and petty traders. 
Table 6. Regression Results (authors' computation, 2019)

\begin{tabular}{|c|c|c|c|c|}
\hline Variable & Coefficient & Std. Error & $t$-Statistic & Prob. \\
\hline$A S S$ & 0.438168 & 0.121159 & 3.616456 & 0.0005 \\
\hline$M M W$ & 0.571656 & 0.232141 & 2.462534 & 0.0156 \\
\hline$P T$ & 0.244663 & 0.093333 & 2.621393 & 0.0102 \\
\hline$C$ & -0.129381 & 0.100177 & -1.291519 & 0.1997 \\
\hline$R$-squared & 0.668791 & & & \\
\hline Adjusted $R$-squared & 0.624578 & & & \\
\hline$F$-statistic & 3.817666 & & & \\
\hline $\operatorname{Prob}(F$-statistic $)$ & 0.003419 & \multicolumn{5}{|l}{ Durbin-Watson stat } & 1.968440 \\
\hline
\end{tabular}

Therefore, the alternate hypotheses for the three hypotheses were validated. Furthermore, the relationships between all the measurements of informal sector tax were positive, which showed that monumental capital development in Lagos Metropolis was brought about by taxes collected from association, market men and women and petty traders in Lagos State, Nigeria.

The result of the $R$-squared was $62.46 \%$, which implied that approximately $62 \%$ of the changes in $C D$ were caused by the independent variable, while the remaining $38 \%$ of the changes were due to other variables not specified in the model. The $F$-statistic measures the overall significance of the explanatory variable in a specified model. The value of the $F$-statistic, according to the results of the regression, was 3.817666 with a probability value of 0.0034 , which was significant at a $5 \%$ critical level. The decision rule for the $F$-statistic is that we reject the null hypothesis when the $F$-statistic is less than a $5 \%$ critical level. The explanatory variable was significant in explaining changes in the dependent variable.

In the regression conducted, the value of the Durbin Watson statistic was 1.9684, which indicated that there was no serial correlation in the model because the value was approaching the value of 2 .

\section{DISCUSSION OF FINDINGS}

The study aimed at examining the effect of informal sector tax revenue on capital development in Lagos Metropolis by collecting the relevant data from the Lagos State Internal Revenue Service. To achieve the broad objective, informal sector tax was measured using tax collected from associations, market men and women and petty traders.

Findings from the study revealed that tax collected from the association, petty traders and market men and women had a significant effect on capital development in Lagos Metropolis. Taxes collected from associations contributed to capital development in the state. The contribution was towards capital projects, such as road construction, building of schools, hospitals and housing, thus increasing the standard of living. The taxes collected from market men and women were used by the government to build markets, parks, and garages to improve the lives of the market men and women. The revenue collected from petty traders was used by the 
government to build stalls and lock-up shops where traders could easily display their wares rather than hawking on the streets. The results were in line with the findings of Adesoji and Chike (2015); Obara and Nangih (2017); Dada, Adebayo, and Adeduro (2017) who established that revenue taxes positively affected economic growth in Nigeria.

\section{CONCLUSION}

The study concludes that taxes from the informal sector have a significant effect on capital development in Lagos Metropolis. It is evident from the monumental capital projects being executed by the government in Lagos Metropolis. Therefore, the government should not only create an enabling environment for the informal sector but also give all necessary support for its survival because the sector has contributed immensely to the capital development of the state. The study recommends the following activities: the government should fashion out strategies to collect taxes from the informal sector in order to run government's operations efficiently; the government should continue with it public enlightenment programmes, which aim at educating associations, market men and women and petty traders on the benefits linked with tax payment; and the government should continue with its capital development programmes by constructing more roads, building hospitals, schools, markets in order to gain the trust of the citizenry.

\section{REFERENCES}

Adam, P. A. (2014). The impact of Human Capital on Economic growth in Nigeria and Human Resources Development in Africa. Proceedings of the Nigeria Economic Society Annual Conference, Ibadan, 20(3), 199-222.

Adeleke, O. B. (2015). The informal sector in Nigeria through the lens of apprenticeship, education, and employment. American Advanced Research in Management, 1(1), 13-20.

Adegboyega, A., Olabisi, J., Kajola, S. O., \& Asaolu, T. O. (2019). Does leverage affect the financial performance of Nigerian firms? Journal of Economics and Management, 37(3), 5-22. http://doi.org/10.22367/jem.2019.37.01

Adesoji, A. A., \& Chike, F. O. (2016). The effect of internal revenue generation on infrastructural development. Journal of Educational and Social Research, 3(2), 419-428.

Adum, S. O. (2018). Burning issues in the Nigeria tax system and tax reforms on revenue generation: Evidence from Rivers state. International Journal of Finance and Accounting, 7(2), 36-44.

Ajadi, T. O. (2015). Private Universities in Nigeria: the Challenges Ahead. American Journal of Scientific Research, 7(1), 15-24.

Ameyaw, B., Oppong, A., Abruquah, L.A., \& Ashley, E. (2016). Informal sector tax compliance issues and the casualty nexus between taxation and economic growth. Scientific Research Publishing, 7(1), 1479-1485.

Appah, E., \& Eze, G. P. (2014). A Causality Analysis between Tax Audit and Tax Compliance in Nigeria. Journal of Educational and Social Research, 3(4), 49-98.

Bhartia, H. L. (2009). Economic growth and indirect tax structure and administration in Nigeria, Journal of Applied Finance and Banking, 16(29), 57-68.

Dada, R. A., Adebayo, I. A., \& Adeduro, O. A. (2017). An assessment of revenue mobilization in Nigeria local government: Problems and prospects. Archives of Business Research, 5(9), 119-121. https://doi.org/10.14738/abr.59.2885

David, C. W. (2016). The theory of Petty Trading: The Jamaican Higgler. The Economic Journal, 106(435), 507-518. https://doi.org/10.2307/2235264

Dirisu, A. O. (2016). Production of Coir-fibre Cement Reinforced Roofing Sheets from coconut Coir Fibre, cement, and Sand. NBRRI Information leaflet on Research and Development works.

Ebufuro, O., Mienye, E., \& Odubo, T.V. (2016). Application of GIS in improving tax revenue from the informal sector in Bayelsa state, Nigeria. International Journal of Scientific and Research Publications, 6(8), 1-7. 
Enahoro, J., \& Olabisi, J. (2014). Tax administration and revenue generation of Lagos state. Archives of Business Research, 4(7), 19-51.

Fagbohun, O. O., \& Obiyemi, O. (2018). Development of an informal sector and tenement tax monitoring and compliance enforcement using the intelligent based electronic policing system. Advances in Research, 13(1), 2-6. https://doi.org/10.9734/AIR/2018/38046

Gilson, L., Russell, S., \& Buse, K. (2015). The Political Economy of user fees with targeting: Developing equitable health financing policy. Journal of International Development, 7(3), 369-401. https://doi.org/10.1002/jid.3380070305

Guillermo, B., \& Deyve, F. A. (2019). The informal economy and its impact on tax revenues and economic growth: The case of Peru, Latin American and OECD countries (1995-2016), 360 Revista Deciencias Delagestion, 4(4), 128-157. https://doi.org/10.18800/360gestion.201904.006

Jolaoso, B. A. (2014). A study of the use of Local Building Materials for Low-Cost Housing in Western Nigeria. Conference Paper, Ahmadu Bello University, Zaria.

Judge, G. G., Griffiths, W. E., Hill, R. C., Lutkepohl, H., \& Lee, T. C. (1985). The theory and practice of Econometrics, ( $2^{\text {nd }}$ ed.), John Wiley, New York.

Kundt, T. C. (2017). Opportunities and challenges for taxing the informal economy and sub-national taxation. Emerging Issues Report, 2(1), 3-15.

Musa, B., \& Acheampong, A. (2014). Innovative measures adopted by petty traders in dealing with challenges of accessing financial credit in Ghana. Research Gate journal, 5(23), 249-253. https://doi.org/10.6007/IJARBSS/v5-i2/1482

Musa, P., \& Ajibade, O. E. (2016). Local government and challenges of revenue allocation in Nigeria: A study of Yewa south local government, Ogun state. Journal of Public Administration, Finance and Law, 10(1), $55-66$.

Obara, L. C., \& Nangih, E. (2017). Taxing the informal sector and revenue generation in developing countries: An empirical investigation from the Rivers state of Nigeria. Journal of Accounting and Financial Management, 3(1), 48-50.

Odoemelam, N. (2018). Taxation alternative source of revenue in Nigeria: Domineering evidence of petroleum profit tax. European Journal of Business and Management, 10(20), 42-48.

Ofoegbu, G. N., Akwu, D. O., \& Oliver, O. (2016). An empirical analysis of the effect of tax revenue on the economic development of Nigeria. International Journal of Asian Social Science, 6(10), 604-608. https://doi.org/10.18488/journal.1/2016.6.10/1.10.604.613

Olaniyi, O. O., \& Adam, J. A. (2015). Public Expenditure and Human Development in Nigeria, $3^{\text {rd }} \& 4^{\text {th }}$ eds., Longman Publishing ltd.

Oduwole, J., \& Sanni, A. (2014). Policy brief on expanding the tax base in the informal sector in Nigeria. A Publication of Civil Society Legislative advocacy, 1-22.

Ramot, I., \& Ichihashi, M. (2015). The effects of tax structure on economic growth and income inequality. Asian Journal of Research in Banking and Finance, 25(76), 217-233.

Scott-Emuakpor, A. (2015). The Evolution of Health care systems in Nigeria: which way forward in the twentyfirst century. Niger Med Journal, 5(1), 53-65.

Soetan, T. A. (2017). Tax administration and tax revenue generation in Nigeria: Taxpayers perspective. International Journal of Latest Engineering and Management Research, 2(10), 38-40.

Udoh, J. E. (2015). Taxing the informal economy in Nigeria: Issues, challenges, and opportunities. International Journal of Business and Social Science, 6(10), 160-169.

Wahdan, M., \& Leithy, W. (2017). Factors affecting the profitability of commercial banks in Egypt over the last 5 years (2011-2015), International Business Management, 11(2), 342-349

\section{AUTHORS' SHORT BIOGRAPHIES}

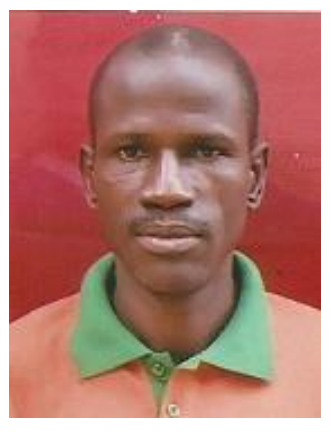

Dr Olabisi Jayeola is a Senior Lecturer at the Department of Accounting, Federal University of Agriculture, Abeokuta, Nigeria. He received his B.Sc., M.Sc., M. Phil., and $\mathrm{PhD}$ in Management Accounting from Obafemi Awolowo University, Osun State; University of Lagos and Babcock University, Ogun State, Nigeria in 2014. Dr Olabisi Jayeola is a Fellow of the Institute of Chartered Accountants of Nigeria (ICAN); Associate Member of Chartered Institute of Taxation of Nigeria; Associate Member of the Nigerian Institute of Management; Associate Member of the Institute of Cost and Management Accountants. His lecturing experience is over fifteen years at different levels within different universities in Nigeria. He has occupied different academic positions within the universities in Nigeria such as Departmental Examination Officer, Head of the Department of Accounting, Deputy Dean of the College and Acting Dean of the College. Dr Olabisi's area of 
specialisation is management accounting, and he is experienced in theoretical and practical aspects of accounting. Currently, he is teaching Financial Accounting, Management Accounting, Oil \& Gas Accounting and Research Methodology to both undergraduate and postgraduate students.

E-mail: Jayeolabisi@yahoo.com and olabisij@funaab.edu.ng

Phone: +2348033549625

ORCID iD: https://orcid.org/0000-0002-5390-0307
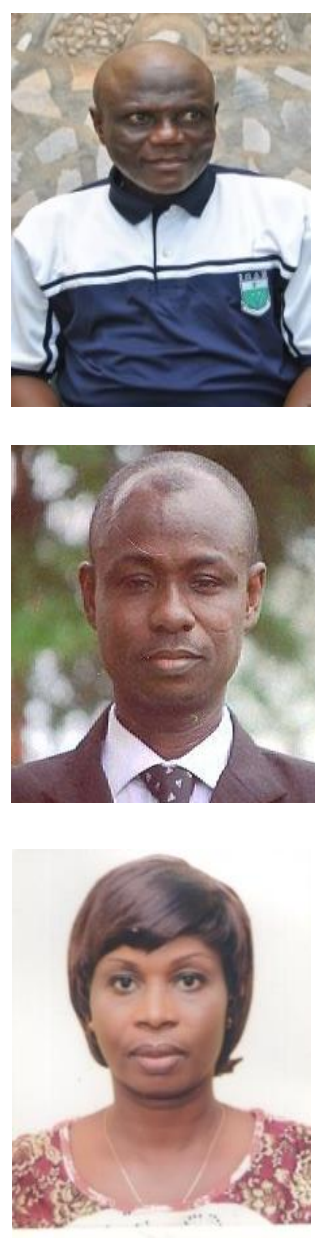

Dr Adegboyega Afolabi obtained his $\mathrm{PhD}$ in Accounting from Babcock University, Ogun State in 2018. He is a fellow of the Institute of Chartered Accountants of Nigeria (ICAN). He is currently a senior lecturer in the department of Accounting and Finance, Crescent University, Abeokuta, Ogun State, Nigeria. he is currently the head of the department of accounting and finance, Crescent University, Ogun State, Nigeria.

Dr Olagun Adebayo is currently an associate professor in the department of accounting and Finance, Osun State University. He obtained his $\mathrm{PhD}$ in Management Accounting from Babcock University, Ogun State in 2013. He has lectured in many Universities in Nigeria. His area of specialisation is Financial Management. He has occupied many academic positions which include Head of Department and Post Graduate Student Coordinator among others.

Mrs Folasade Ajewole Madariola obtained a Higher National Diploma in accountancy from Ogun State Polytechnic (now, Moshood Abiola Polytechnic, Ogun State). She had a Bachelor of Science Degree in Accountancy from Crescent University, Ogun State. She also holds a Master of Business Administration from Ladoke Akintola University of Technology, Oyo State. She is an associate member of Chartered Institute of Taxation of Nigeria (CITN). Currently, she is the chief accountant of Moshood Abiola Polytechnic, Ogun State, Nigeria. 